\title{
Дарья Хлевнюк
}

Сергей Ушакин и Алексей Голубев, ред. и сост. XX век: Письма войны. М.: Новое литературное обозрение, 2016. 832 с. ISBN 978-5-4448-0571-8.

Дарья Хлевнюк - аспирант (PhD candidate) Государственного университета Нью-Йорка в Стоуни Брук (State University of New York at Stony Brook). Адрес для переписки: Department of Sociology, State University of New York at Stony Brook, Stony Brook, NY 11794-4356, USA. daria.khlevnyuk@stonybrook.edu.

Память о войнах всегда была особенно важна для обществ. Прошлые распри становились поводом для новых сражений, победы - гордостью для будущих поколений. Традиционно военная история рассказывалась в жанре эпоса, с упором на триумф. Неудивительны поэтому огромные памятники военачальникам и триумфальные арки в Европе. Даже личные истории и воспоминания солдат укладывались в этот героический нарратив. Выросшие в СССР и постсоветской России наверняка помнят ветеранов, которые приходили в школы и рассказывали удивительные истории мужества. Однако их историям о трудностях, бытовых проблемах, страхе за себя и семью, непонимании происходящего и попытках обжиться в повседневности войны просто не было места в этом формате. Постепенно, впрочем, эти истории стали появляться на свет. Так, недавний нобелевский лауреат Светлана Алексиевич записывала воспоминания участвовавших в Великой Отечественной войне женщин, которых отнюдь не всегда воспринимали как ветеранов и героев и которым очень тяжело было сочетать роли жен и солдат или медсестер (Алексиевич 2017), а потом афганцев молодых ребят, которые зачастую шли на войну под впечатлением от рассказов ветеранов, но не находили в ней ни героизма, ни великой цели (Алексиевич 2014). Таким же отрезвляющим от некончающегося в России последние несколько лет праздника Победы (бум этого культа подробно исследован в том числе в источниках: Гудков 2005; Левинсон 2005; Brandenberger 2009; Kucherenko 2011; Nelson 2015; Sherlock 2007) может стать вышедший в издательстве НЛО сборник «XX век: Письма войны» под редакцией Сергея Ушакина и Алексея Голубева.

«Письма войны» - далеко не первый сборник военной корреспонденции, опубликованный в последние несколько лет. Можно вспомнить такие работы, как «Письма во власть в эпоху революции и Гражданской войны» (Шишкин 2017), «"Я пока жив..." (Фронтовые письма 1941-1945 гг.)» (Гусев 2010), «“Много писать мне мешали бои...": фронтовые записи 1941-1945 годов» (Минаева и Николаев 2005). В основном такие сборники посвящены какому-то определенному периоду (например, Гражданской или Великой Отечественной войне). Часто среди целей составители заявляют «ввод документов в научный оборот». Иными словами, корреспонденция для них - это документы, которые полезны в изучении истории того или иного события. Письма из сборника Ушакина и Голубева относятся к разным 
периодам, они написаны во времена нескольких войн: Русско-японской, Первой мировой, Великой Отечественной, Афганской и Чеченских войн. Письма были собраны из разных источников: государственных и личных архивов, музеев. Их авторы - очень разные люди: представители разных поколений, социальных слоев. Авторы сборника не стремятся обнаружить в письмах недостающую историческую информацию, восстановить ход событий.

Поскольку ввод писем в научный оборот не заявлен в качестве ключевых целей книги, логика отбора писем тоже отличается от других сборников. Составители «Писем войны» не показывают нам самые яркие письма - те, в которых обозначенная тема раскрывается наиболее полно. Напротив, сама практика отбора писем, выбор цитат отбрасывается редакторами, потому что «"яркость", “показательность" и "информативность" - это категории, не имеющие устойчивого содержания» (с. 12). К сожалению, не вполне ясно, каким же принципом составители руководствовались при отборе документов и какие письма и почему не были включены в итоговый сборник.

Составители предлагают посмотреть на войны как на антропологический опыт, а на практику писания писем - как на часть этого опыта. То есть их не интересует история, фронтовой быт или антропология солдат какой-то одной войны. Нет, они предлагают сравнить военную корреспонденцию разных времен и обнаружить в ней базовые элементы опыта войны вообще. В связи с этим, по-видимому, предпочтение отдавалось сериям писем, через которые опыт войны показывается в динамике.

Письма Виталия Зайцева, воевавшего в Чечне, читаются практически как роман в письмах. Ему 18 лет, он уходит в армию. Здесь плохо кормят, дедовщина, болезни, несчастные случаи, а впереди - война в Чечне. Сначала он еще старается не волновать свою семью, но через некоторое время просит помочь сбежать:

«Мне очень хочется просто отсюда уехать. Теперь-то я, наконец, понял, что такое армия и что такое война, хотя я там еще и не был. Лучше я был бы дома примерным мальчиком и ходил бы перед вами на цыпочках, чем здесь 1,5 года торчать. Мне кажется, что хуже, чем здесь, места нигде и нет [...]. Насчет документов: я могу здесь все забрать, даже никто и не узнает, и военный билет с ними, и потом что захочу, то и сделаю [...]. Конечно, если бы Вы приехали ко мне с формой гражданской и паспортом, это было бы очень просто. Нас здесь еще никто не знает, только по документам, а если их не будет, никто ничего и не узнает. А у нас в военкомате отдали бы их и что-то решили бы» (c. 331).

В следующих письмах Зайцев пишет о войне, о том, как погибают его приятели, как выглядят на самом деле военные операции, о которых рассказывают по телевизору. Последние письма в подборке уже не от Виталия. Одно из них - от командира роты: «Извиняемся, что не смогли уберечь Вашего сына, но мы будем помнить его» (с. 349).

В чем суть антропологического подхода составителей сборника? Ушакин и Голубев показывают «организационные особенности письма» и «устойчивую по- 
вторяемость тем, сюжетов, стилистических и структурных приемов, с помощью которых военная корреспонденция сложилась как особый жанр» (с. 14). Так что разделы в сборнике не случайны; по мнению авторов, это «тематические якоря» (с. 14) военной корреспонденции. В начале каждого раздела - введение, автор которого объясняет суть соответствующего тематического якоря, как он проявляется в письмах, на что стоит обратить внимание. Всего таких разделов 13, они покрывают основные темы писем: деньги, быт, романтические отношения, плен, смерть и пр.

Несмотря на то, что для читателя остается скорее загадкой, как были выбраны эти темы, - составителям сборника легко поверить. Действительно, во многих из писем собственно военные действия оказываются скорее декорацией. Военных и их адресатов волнуют другие вопросы. Дошли ли до родных деньги и на что они были потрачены? Как сохранить брак во время войны? Кто из близких где оказался? Как растут дети? Осталась ли девочка из соседнего двора такой же красивой? Поэтому тем, кто ищет в этих письмах исторические документы, некоторые из них могут показаться бессодержательными и откровенно скучными. Например, автор серии писем может снова и снова отправлять короткие замечания о том, сколько денег он послал и как их нужно использовать. Особенно это заметно в разделе «Гнет войны». В письмах этого раздела трудно разглядеть масштаб войн. Их авторов, как и большинство из нас, волнует здоровье, судьба близких. Что для них война? Неопределенность, непонимание того, что происходит, почему и куда их перебрасывают, что их ждет; усталость и скука, фатализм по отношению к смерти. Автор введения - Дмитрий Мордвинов - пишет: «В этом смысле письма раздела являются самым сильным противоядием от тех идеологических конструкций, которые глорифицируют войну, представляя ее исключительно с позиций геройства, побед и славы, зачеркивая при этом ее черную повседневность» (с. 261).

Истории любви (им посвящено два раздела сборника) в этих письмах тоже выглядят не так грандиозно и однозначно, как в наших любимых советских фильмах: здесь и ревность, и сомнения, и надежды. Одному солдату месяцами не пишет жена. Он же продолжает писать то обиженно, то умоляя ее отозваться. Кто-то требует от жены отчета о том, как она себя ведет в отсутствие мужа. Переписка между супругами периодически перемежается взаимными упреками о долгих периодах без ответа: «Миленький Восичка, еще я хочу сообщить о том, что я как замечаю, ты на меня обидился, что стал редко слать письмы, получила я только ответ за двадцать второе число октября, а то более не получила, а сейчас уже 27 ноября, уже более месяца, а я, миленькай Восичка, на каждая письма даю по три, по четыре ответа» (с. 642). Есть, впрочем, и примеры невероятных историй любви - таких, например, как переписка Раи Клейман и Марка Файноба, удивительным образом сохранившаяся у их дочери - несколько сотен писем. Вообще романтическая переписка занимает в этом сборнике значительное место. Ведь даже вопросы о деньгах, жалобы на нехватку еды, холод - все это на самом деле о человеческих отношениях. В некотором смысле это сборник не столько про войну, сколько, как бы сентиментально это ни звучало, про любовь. Про любовь, 
которая обостряется в таких экстремальных обстоятельствах, когда и сами люди, и их отношения в опасности. И письма оказываются единственным способом поддержания этой связи, а их авторам приходится искать язык для разговора о любви.

В смешении тем, собственно, и состоит основная проблема сборника. Предложенная тематизация писем позволяет взглянуть на военную корреспонденцию с иной точки зрения, увидеть базовые элементы, на которые раскладываются письма. Но разделение писем на темы - и авторы сами оговаривают это в предисловии - не всегда безусловно. Например, отнесенная в раздел про денежные отношения серия писем Андрея Ипатова - это и история про попытку поддерживать семейные отношения, поскольку часть писем адресована детям. Помимо денег обсуждаются родственники, соседи и друзья, планы на будущее и текущий быт. И наоборот, вопросы о денежных переводах и посылках появляются во многих других разделах: это вообще чуть ли не обязательный пункт корреспонденции между родственниками. Поэтому выходит, что тематизация сборника достаточно условна. Читатель, заинтересованный в одной из тем, все равно должен будет прочесть книгу полностью. Более того, формат книги скорее всего просто не подходит для адекватного разбора писем по темам. Так как в каждом письме присутствует сразу несколько тем, лучше всего это могло бы быть показано системой тегов, которая возможна только в электронных проектах вроде «Прожито» ${ }^{1}$.

Сборник «Письма войны» - весомое исследование в прямом и переносном смысле. Трудно представить, какая громадная работа была проведена для подготовки этой книги, сколько писем было прочитано, как тяжело было выбрать одни и не опубликовать другие. Книга читается легко, почти как художественный текст, но это многостраничный том, за который возьмется не каждый читатель. Более того, не каждому читателю будет понятно, для кого этот сборник подготовлен. Несомненную ценность представляет описание подхода составителей и анализ использования тематических якорей в предисловиях к разделам. Это отдельный научный труд и почти что отдельная книга. Однако писем в разделах слишком много, чтобы считать их просто иллюстративным материалом к этой научной работе. Письма же складываются как бы в отдельную книгу, которую, впрочем, трудно воспринимать как тематический сборник писем в связи с вышеупомянутыми проблемами рубрикации.

Возможно, «Письма войны» только выиграли бы от уменьшения объема и отказа от жесткого формата тематизации, однако в любом случае книгу стоит прочесть, и читать ее надо целиком, почти как произведение художественной литературы. Двойственность сборника, сосуществование под одной обложкой двух достаточно самостоятельных книг мне представляется и его недостатком, и, в общем-то, достоинством. Чтение этого сборника - это почти что антропологическое погружение в опыт военной корреспонденции (благодаря хорошо отобранным письмам), в котором читателя сопровождают опытные исследователи, поясняющие, на что стоит обращать внимание и к чему в письмах присмотреться.

${ }^{1}$ http://prozhito.org. 


\section{СПИСОК ЛИТЕРАТУРЫ}

Алексиевич, Светлана. 2014. Цинковые мальчики. М.: Время.

Алексиевич, Светлана. 2017. У войны не женское лицо. М.: Время.

Гудков, Лев. 2005. «"Память" о войне и массовая идентичность россиян». Неприкосновенный заnac (2-3):40-41.

Гусев, Михаил, сост. 2010. «Я пока жив...» (Фронтовые письма 1941-1945 г2.). Н. Новгород: Комитет по делам архивов Нижегородской области.

Левинсон, Алексей. 2005. «Война, войны, войне...». Неприкосновенный запас (23):40-41.

Минаева, Анна и Олег Николаев, сост. 2005. «Много писать мне мешали бои...»: фронтовые записи 1941-1945 годов. М.: Новое издательство.

Шишкин, Владимир, ред. 2017. Письма во власть в эпоху революции и Гражданской войны (март 1917 - ноябрь 1919 г.). Новосибирск: Параллель.

Brandenberger, David. 2009. “A New Short Course? A. V. Filippov and the Russian State's Search for a 'Usable Past."' Kritika: Explorations in Russian and Eurasian History 10(4):825-833.

Kucherenko, Olga. 2011. "That'll Teach'em to Love Their Motherland!: Russian Youth Revisit the Battles of World War II." Journal of Power Institutions in Post-Soviet Societies 12. Retrieved June 28, 2015 (http://pipss.revues.org/3866?lang=en\&gathStatIcon=true).

Nelson, Todd H. 2015. "History as Ideology: The Portrayal of Stalinism and the Great Patriotic War in Contemporary Russian High School Textbooks." Post-Soviet Affairs 31(1):37-65.

Sherlock, Thomas. 2007. Historical Narratives in the Soviet Union and Post-Soviet Russia: Destroying the Settled Past, Creating an Uncertain Future. New York: Palgrave Macmillan. 